\title{
Attitude of Hausa ESL Secondary School Students Towards Spelling and Writing in English
}

Muhammad Mukhtar Aliyu ${ }^{1}$, Gambo A. Danladi ${ }^{2}$

1Department of English and Literary Studies, Bauchi State University, Gadau-Nigeria

2Department of Foundation, Aminu Saleh College of Education, Azare Nigeria

Email: aliyumuhammadmukhtar39@gmail.com

How to cite this paper: Aliyu, M., \& Danladi, G. (2018). Attitude of Hausa ESL Secondary School Students Towards Spelling and Writing in English. International Journal ot Language Teaching and Education, 2(3), 184-194.

https://doi.org/10.22437/ijolte.v2i3.5908

Accepted: October 18, 2018

Published: November 30, 2018

Copyright (C) International Journal of Language Teaching and Education.

This work is licensed under the Creative Commons Attribution International License (CC BY 4.0).

http://creativecommons.org/licenses/by/4 $.0 /$

\section{cc) (i)}

\section{Abstract}

Writing skill is described as an essential language tool for students. Studies have shown that Hausa ESL secondary school students commit various errors in their writing in English. Various factors have been identified as responsible for the problems. However, the students' attitude towards spelling and writing has not been investigated. It is believed that students' attitude plays an important role in motivating and influencing their secondlanguage learning. Therefore, the aim of this study is to explore the attitude and perception of Hausa ESL secondary school students towards English spelling and writing. The study adopts a survey research design where an intact class of 75 students from a secondary school in north-eastern Nigeria was selected. To collect the data for the study, a questionnaire was employed. The questionnaire comprises two sections: (i) attitudes toward English spelling and (ii) attitudes toward writing in English which include four writing purposes: (a) School Use, (b) Social Use, (c) Official Use, and (d) Creativity. Findings of the study revealed that the participants have a moderate positive attitude and perception towards English spelling and writing. The findings also indicated that the students' attitude toward the School Use of English is the highest, whereas their Creativity in writing has the lowest means among the four purposes. In addition, the study revealed that there is a significant positive relationship between the participants' attitude towards spelling and writing. To enhance students' creative writing and thinking skills, the study suggests that literature in English should be made compulsory to all secondary school students. Story-reading and creative writing should be incorporated into the curriculum. Other extracurricular activities such as spelling completion should be organized to help the students.

\section{Subject Areas}

Writing

Keywords

Attitude, ESL, Hausa, Spelling, Writing 


\section{Introduction}

Among In academic institutions, developing a good command of students' written English is one of the desires of teachers most especially in countries where English is adopted as a second (ESL) or foreign language (EFL). For instance, in Nigeria, a good writing skill in English is important to both academic and non-academic lives of individuals. In academic institutions, English is used as the medium of instruction, thus, writing in English is largely considered as a multifunctional tool used by students to take class notes, write assignment, tests, and examinations. According to some researchers, one's success in school is measured mainly through writing as it is used by the instructors to evaluate the quality of students' learning and thinking (Murray \& Hughes, 2008). In addition, proficiency in writing English remains one of the most important skills required for admission into higher institutions and the labor market as English is the official language of the country (Dabalen et al., 2000; Tikolo, 2012).

Closely related to writing is spelling. It is considered one of the essential literacy skills and writing components that enable readers to understand the written message clearly. Learning to spell words accurately is very important to language learners because incorrect spelling can result to misunderstanding and unsuccessful communication between the writer and the reader. Accurate spelling shows a writer's mastery of a language and creates a good impression of his/her academic position. It also contributes to the learner's selfconcept which enables the learners to communicate adequately in writing (Peters, 2013). Acquiring spelling skills is a gradual process and it needs effort not only mere memorization (Gentry, 2000). Also, to learn to spell accurately, students need to understand the sound as well as the internal structure of words such as suffixes and prefixes. They should also acquire some semantic knowledge for words that look or sound the same homophones and homographs. Finally, they should possess good visual memory to compare the shape of the new word with a similar word learnt previously (Mpiti, 2012). Despite the importance of writing in English, numerous researchers have shown that many Nigerian secondary school students cannot produce good writing in English (Adepoju \& Oluchukwu, 2011). This has been evident from the WAEC results of some secondary schools in Nigeria where students (larger percentage) have continually failed the English language (Odochi Silver \& Ephraim, 2012). Various factors have identified as responsible for the students' poor performance in writing in English. These include mother tongue influences, learning environment, poor methods of teaching, lack of good teaching, poor language, and the nature of teacher/student interaction. In addition, spelling English words has also been a challenging task for many Hausa ESL secondary school students. One of the reasons is that Hausa is a 
phonetic-based language where words are written as they are pronounced while English is the other way around. In English, there is no inconsistency between the sounds and the letters. Some letters are pronounced differently while others are silent (not pronounced) such as know, hour, listen, psychiatric and empty. This causes confusion for many Hausa learners of English and made them spell some English words incorrectly.

One of the factors many scholars neglect, in their attempts to investigate the students' writing problems, is learners' attitudes towards writing and spelling in English. Studies have shown that students' positive attitudes enhance second language learning (Hashemian \& Heidari, 2013). Attitude is described as an evaluative reaction inferred based on the individual's positive or negative feelings, beliefs or opinions about any topic (Gardner, 1985). Brown (2007) describes attitude as a set of beliefs that a learner holds toward the target language whether it is important, interesting, boring, and so forth. Other scholars such as Gardner and Lambert (1972) assert that attitude is a crucial motivational ingredient, which actively contributes to learning another language. However, there is a lack of studies that investigate the Hausa ESL students' attitudes towards English writing and spelling especially in secondary schools in Nigeria.

Therefore, the purpose of this study is to investigate the attitudes of Hausa ESL secondary school students towards English spelling and writing. It also wants to evaluate the relationship between the students' attitudes towards spelling and writing in English.

\section{Methodology}

This study adopted a cross-sectional survey design. Under this design, the researcher collected data from the participants at one point in time. Quantitative data were collected from the participants. The data were analyzed and used to answer the research questions.

The subjects of the study are an intact class of Senior Secondary Student Two (SS 2) in north-eastern Nigeria. The total number of the subjects is 75, 30 males and 45 females, with their ages ranging from 16-19 years old. All the subjects attended and completed Junior Secondary School (JSS1-3) and Senior Secondary Student One (SS 1).

A set of a questionnaire designed in a Likert-scale form was employed to elicit data on the subjects' attitude towards spelling and writing in English. The questionnaire is adopted from Al-Sobhi Rashid and Abdullah (2018). It comprises two sections: (a) attitudes toward English spelling which contains 18 items. The items include different areas related to English spelling such as the importance of spelling, the student's perceptions and confidence about themselves as spellers and the challenges that the students encounter while 
spelling out English words such as silent letters. The items also include other topics like the students' performance on spelling tests, the use of English dictionaries, and spell-check programs. Section (b) attitude toward writing in English which is further subdivided into four subsections purposes for writing: (a) School Use with 10 items; (b) Social Use, (c) Official Use, and (d) Creativity with eight items each. To ensure the validity of the instrument, the questionnaire was tested and validated by a panel of expert which certified its content validity. To ensure its reliability, Cronbach's alpha was calculated and found .94 which indicates the high reliability of the questionnaire. In addition, to facilitate the subjects' comprehension of the items, the researchers explained every unclear item to them.

Before collecting the data, the researchers obtained permission from the School Principal. They also solicited for the consent of the subjects. Having obtained their consent, the researchers explained the purpose of the study and assured them of confidentiality. Thereafter, the questionnaire was administered to the subjects and they were asked to fill in. While they were filling in the questionnaire, the researchers went around the class to help them and answer any question or make clarifications on some unclear items. After, filling out the questionnaire, the researchers retrieved all the questionnaire.

\section{Finding and Discussions}

To address the first and second research questions on the students' attitudes towards spelling and writing in English, the data collected from the questionnaire were analyzed using descriptive statistical analysis, where mean and frequency were calculated. In addition, to answer the third research question which is to examine the relationship between the secondary school students' attitude towards spelling and writing in English, the Pearson correlation coefficient was computed. The results are presented in the following sections followed by discussions.

\subsection{Respondents' Attitude Towards English Spelling}

This section addresses research question 1 of the study. It presents the respondents' attitudes towards English spelling. The results of the descriptive statistical analysis are presented in Table 1 below. 
Table 1. Attitudes toward English spelling

\begin{tabular}{|c|c|c|c|c|c|c|c|c|}
\hline & Items & 1 & 2 & 3 & 4 & 5 & Mean & SD \\
\hline 1 & Spelling is important. & 4.0 & 0 & 2.7 & 21.3 & 72 & 4.57 & .887 \\
\hline 2 & I am a good speller. & 0 & 0 & 21.3 & 40.0 & 38.7 & 4.17 & .760 \\
\hline 3 & $\begin{array}{l}\text { I am a weak speller because I don't like } \\
\text { writing. }\end{array}$ & 25.3 & 22.7 & 17.3 & 22.7 & 12.0 & 2.73 & 1.37 \\
\hline 4 & $\begin{array}{l}\text { I don't like other people to see what I have } \\
\text { written because of my spelling errors. }\end{array}$ & 25.3 & 30.7 & 6.7 & 21.3 & 16.0 & 2.72 & 1.45 \\
\hline 5 & $\begin{array}{l}\text { Getting } 100 \% \text { on a spelling test is luck, not } \\
\text { ability. }\end{array}$ & 16.0 & 6.7 & 5.3 & 37.3 & 34.7 & 3.68 & 1.42 \\
\hline 6 & I have always struggled with spelling. & 9.3 & 29.3 & 21.3 & 16.0 & 24.0 & 3.16 & 1.33 \\
\hline 7 & $\begin{array}{l}\text { Words that have silent letters are difficult } \\
\text { to spell. }\end{array}$ & 10.7 & 4.0 & 16.0 & 37.3 & 32.0 & 3.76 & 1.25 \\
\hline 8 & Spelling is my favorite subject. & 4.0 & 0 & 5.3 & 17.3 & 73.3 & 4.56 & .918 \\
\hline 9 & $\begin{array}{l}\text { Knowing the spelling rules helps me to } \\
\text { spell many words. }\end{array}$ & 0 & 12.0 & 8.0 & 21.3 & 58.7 & 4.26 & 1.04 \\
\hline 10 & $\begin{array}{l}\text { The more I write, the more my spelling im- } \\
\text { proves. }\end{array}$ & 0 & 0 & 6.7 & 17.3 & 76.0 & 4.69 & .592 \\
\hline 11 & I always do well on spelling tests. & 10.7 & 5.3 & 29.3 & 40.0 & 14.7 & 3.42 & 1.14 \\
\hline 12 & $\begin{array}{l}\text { There is no need to learn how to spell be- } \\
\text { cause there are computer programs which } \\
\text { correct my spelling. }\end{array}$ & 53.3 & 30.7 & 12.0 & 0 & 4.0 & 1.70 & .969 \\
\hline 13 & $\begin{array}{l}\text { To me, English spelling is more difficult } \\
\text { than Hausa spelling. }\end{array}$ & 24.0 & 20.0 & 6.7 & 13.3 & 36.0 & 3.17 & 1.65 \\
\hline 14 & $\begin{array}{l}\text { I always use a spell checker on my com- } \\
\text { puter to check my spelling. }\end{array}$ & 9.3 & 26.7 & 20.0 & 8.0 & 36.0 & 3.34 & 1.43 \\
\hline 15 & $\begin{array}{l}\text { When I write, I can tell if a word does not } \\
\text { look right. }\end{array}$ & 6.7 & 4.0 & 9.3 & 28.0 & 52.0 & 4.14 & 1.17 \\
\hline 16 & $\begin{array}{l}\text { When I write, I always choose words I } \\
\text { know I can spell. }\end{array}$ & 8.0 & 10.7 & 2.7 & 25.3 & 53.3 & 4.05 & 1.31 \\
\hline 17 & $\begin{array}{l}\text { I always use a dictionary to check the } \\
\text { spelling of unfamiliar words. }\end{array}$ & 2.7 & 0 & 4.0 & 42.7 & 50.7 & 4.38 & .803 \\
\hline 18 & $\begin{array}{l}\text { After writing a sentence, I always check my } \\
\text { spelling errors. }\end{array}$ & 5.3 & 6.7 & 4.0 & 17.3 & 66.7 & 4.33 & 1.16 \\
\hline
\end{tabular}

The results of this study showed that the Hausa ESL respondents' overall attitude toward English spelling is positive. From the Table, it could be seen that the three-uppermost means of their attitude toward spelling are in items 10, 1 and 8. The highest means among all the other spelling attitude items is item 10 "The more I write, the more my spelling improves" $(\mathrm{M}=4.69$ and SD = 0.59). The results show that majority of the respondents (76\%) strongly agreed that the more they write, the more their spelling improves. The second highest means is item 1 "Spelling is important" $(\mathrm{M}=4.57$ and $\mathrm{SD}=0.90)$ which shows that $72 \%$ of the respondents strongly agreed. Finally, item 8 "Spelling is my favorite subject" is third highest among all the spelling items $(\mathrm{M}=4.56$ and $\mathrm{SD}=.91)$ where $73.3 \%$ of the respondents strongly agreed with. 


\subsection{Respondents' Attitude Towards English Writing}

This section addresses This section presents the findings of the second research question, which explored the respondents' attitudes towards English writing. The statistical results of the quantitative data are presented. As stated earlier, the students' attitude toward writing in English was measured by 34 items distributed among four subscales, with 10 items for (a) School Use and eight items for each of the other subscales, (b) Social Use, (c) Official Use, and (d) Creativity. A descriptive statistical analysis was run on the questionnaire. The results are presented in Tables 2-5 respectively. Table 2 presents the respondents' attitudes towards official used of English writing.

Table 2. Attitudes toward writing in English (school use)

\begin{tabular}{|c|c|c|c|c|c|c|c|c|}
\hline & Items & 1 & 2 & 3 & 4 & 5 & Mean & SD \\
\hline 1 & I like English writing classes. & 2.7 & 4.0 & 00 & 26.7 & 66.7 & 4.50 & .906 \\
\hline 2 & I write summaries of what I learn in my classes. & 13.3 & 18.7 & 26.7 & 32.0 & 9.3 & 3.05 & 1.19 \\
\hline 3 & $\begin{array}{l}\text { I enjoy taking part in writing activities and com- } \\
\text { petitions. }\end{array}$ & 9.3 & 20.0 & 17.3 & 33.3 & 20.0 & 3.34 & 1.26 \\
\hline 4 & $\begin{array}{l}\text { I volunteer writing answers on the board if the } \\
\text { teacher asks. }\end{array}$ & 00 & 2.7 & 22.7 & 38.7 & 36.0 & 4.08 & .834 \\
\hline 5 & $\begin{array}{l}\text { I enjoy doing my written assignments and re- } \\
\text { ports. }\end{array}$ & 00 & 10.7 & 4.0 & 20.0 & 65.3 & 4.40 & .986 \\
\hline 6 & I discuss what I write with my classmates. & 10.7 & 10.7 & 10.7 & 18.7 & 49.3 & 3.85 & 1.41 \\
\hline 7 & I feel confident when I sit for a writing exam. & 4.0 & 2.7 & 2.7 & 16.0 & 74.7 & 4.54 & .976 \\
\hline 8 & $\begin{array}{l}\text { I believe I can get a high score in my writing ex- } \\
\text { ams. }\end{array}$ & 6.7 & 2.7 & 13.3 & 24.0 & 53.3 & 4.14 & 1.17 \\
\hline 9 & $\begin{array}{l}\text { I read writings from various authors to improve } \\
\text { my writing. }\end{array}$ & 6.7 & 6.7 & 20.0 & 49.3 & 17.3 & 3.76 & 1.27 \\
\hline 10 & $\begin{array}{l}\text { My knowledge of English grammar and vocabu- } \\
\text { lary does not help me to write well. }\end{array}$ & 38.7 & 9.3 & 12.0 & 16.0 & 24.0 & 2.77 & 1.65 \\
\hline
\end{tabular}

The results show that most of the respondents have positive attitudes towards writing in English. For instance, the three items with the highest mean scores. The first item is "I feel confident when I sit for a writing exam" (M= $4.55 \mathrm{SD}=.976)$ with $74.7 \%$ of the respondents strongly agreed that they feel confident when they sit for a writing exam. The second item with the highest means is "I like English writing classes" $(\mathrm{M}=4.51 \mathrm{SD}=.91)$ where $66.7 \%$ of the students strongly agreed that they like the English classes. The last item with the highest means is "I enjoy doing my written assignments and reports" $(\mathrm{M}=4.40 \mathrm{SD}=.987)$ in which $65.3 \%$ of the students strongly agreed that they enjoy doing their written assignments and reports. 
Table 3. Attitudes towards Social Purposes of Writing in English

\begin{tabular}{|c|c|c|c|c|c|c|c|c|}
\hline & Items & 1 & 2 & 3 & 4 & 5 & Mean & SD \\
\hline 1 & $\begin{array}{l}\text { I enjoy writing letters to my family members and } \\
\text { friends. }\end{array}$ & 4.0 & 12.0 & 10.7 & 36.0 & 37.3 & 3.90 & 1.15 \\
\hline 2 & $\begin{array}{l}\text { I send written cards to invite my friends to social } \\
\text { events. }\end{array}$ & 12.0 & 16.0 & 20.0 & 22.7 & 29.3 & 3.41 & 1.37 \\
\hline 3 & I enjoy texting my family members and friends. & 00 & 8.0 & 24.0 & 36.0 & 32.0 & 3.92 & .940 \\
\hline 4 & $\begin{array}{l}\text { I keep in touch with others through texting and writ- } \\
\text { ing notes/letters. }\end{array}$ & 4.0 & 00 & 26.7 & 42.7 & 26.7 & 3.88 & .943 \\
\hline 5 & $\begin{array}{l}\text { I feel comfortable sharing what I write with my fam- } \\
\text { ily and friends. }\end{array}$ & 6.7 & 00 & 10.7 & 41.3 & 41.3 & 4.10 & 1.06 \\
\hline 6 & I communicate through e-mail often with my friends. & 18.7 & 10.7 & 14.7 & 21.3 & 34.7 & 3.42 & 1.51 \\
\hline 7 & $\begin{array}{l}\text { I enjoy sending thank-you letters to my family mem- } \\
\text { bers and friends. }\end{array}$ & 6.7 & 10.7 & 14.7 & 32.0 & 36.0 & 3.80 & 1.23 \\
\hline 8 & $\begin{array}{l}\text { I write my opinion about things via social networking } \\
\text { sites. }\end{array}$ & 5.3 & 30.7 & 28.0 & 20.0 & 16.0 & 3.10 & 1.16 \\
\hline
\end{tabular}

Table 3 above displays the results of the respondents' attitudes towards English writing for social purposes. Though the overall result is positive, it is not as that of school use where the respondents have the highest positive attitudes. For example, item $5(\mathrm{M}=4.11 \mathrm{SD}=1.060)$ reveals that $41.3 \%$ of the respondents strongly agreed that they feel comfortable sharing what they write with their family and friends. In addition, item $3(\mathrm{M}=3.92 \mathrm{SD}=.941)$ shows that $32 \%$ of the respondents strongly agreed that they enjoy texting my family members and friends. Finally, item $1(\mathrm{M}=3.91 \mathrm{SD}=1.15)$ also shows that $37.3 \%$ of the respondents strongly agreed that they enjoy writing letters to their family members and friends.

Table 4. Attitudes official purposes of writing in English

\begin{tabular}{|c|c|c|c|c|c|c|c|c|}
\hline & Items & 1 & 2 & 3 & 4 & 5 & Mean & SD \\
\hline$\overline{1}$ & $\begin{array}{l}\text { I can write an official letter to (the school princi- } \\
\text { pal, teachers, etc.). }\end{array}$ & 17.3 & 10.7 & 22.7 & 32.0 & 17.3 & 3.21 & 1.33 \\
\hline 2 & $\begin{array}{l}\text { I can write a letter or an e-mail to express my opin- } \\
\text { ion about a topic. }\end{array}$ & 8.0 & 6.7 & 10.7 & 52.0 & 22.7 & 3.74 & 1.12 \\
\hline 3 & $\begin{array}{l}\text { I can write a report about what I have heard or } \\
\text { read. }\end{array}$ & 2.7 & 8.0 & 16.0 & 48.0 & 25.3 & 3.85 & .982 \\
\hline 4 & I feel confident when I write to my teacher. & 4.0 & 8.0 & 9.3 & 25.3 & 53.3 & 4.16 & 1.13 \\
\hline 5 & $\begin{array}{l}\text { I wish I would write a weekly article for a news- } \\
\text { paper or magazine. }\end{array}$ & 6.7 & 14.7 & 22.7 & 32.0 & 24.0 & 3.52 & 1.20 \\
\hline 6 & $\begin{array}{l}\text { I do not feel comfortable when I write an official } \\
\text { letter, e-mail, or report. }\end{array}$ & 32.0 & 6.7 & 17.3 & 28.0 & 16.0 & 2.89 & 1.51 \\
\hline 7 & $\begin{array}{l}\text { Reading official texts helps me write a good appli- } \\
\text { cation letter for the university. }\end{array}$ & 2.7 & 4.0 & 2.7 & 29.3 & 61.3 & 4.42 & .932 \\
\hline 8 & $\begin{array}{l}\text { Because of everyday informal English, I find writ- } \\
\text { ing using formal English difficult. }\end{array}$ & 4.0 & 16.0 & 32.0 & 28.0 & 20.0 & 3.44 & 1.11 \\
\hline
\end{tabular}

As for the for the respondents' attitudes towards writing in English for official purposes, the results also display their positive attitudes. This could be seen in the three items with the highest mean scores. Item 7 has the highest means $(\mathrm{M}=4.42 \mathrm{SD}=.932)$ which shows that majority of the respondents $(61.3 \%)$ strongly agree that reading official texts helps them to write better. Item 4 
$(M=4.16 \mathrm{SD}=1.139)$ also shows that $53.3 \%$ of the students strongly agreed that they feel confident when they write to their teachers. Finally, item 3 ( $M=$ $3.85 \mathrm{SD}=.982$ ) reveals that $48 \%$ of the respondents agree that they can write a report about what they have heard or read

Table 5. Attitudes towards creative writing in English

\begin{tabular}{|c|c|c|c|c|c|c|c|c|}
\hline & Items & 1 & 2 & 3 & 4 & 5 & Mean & SD \\
\hline 1 & I am a creative writer. & 13.3 & 10.7 & 13.3 & 37.3 & 25.3 & 3.50 & 1.33 \\
\hline 2 & I can make up short stories or a poem. & 2.7 & 9.3 & 26.7 & 28.0 & 33.3 & 3.80 & 1.09 \\
\hline 3 & $\begin{array}{l}\text { When I write I can support my topic with a lot of } \\
\text { ideas. }\end{array}$ & 6.7 & 2.7 & 14.7 & 36.0 & 40.0 & 4.00 & 1.12 \\
\hline 4 & Creativity is not necessary for writing an essay. & 18.7 & 2.7 & 30.7 & 36.0 & 12.0 & 3.20 & 1.26 \\
\hline 5 & $\begin{array}{l}\text { When I write, I use similes, descriptive phrases, and } \\
\text { idioms. }\end{array}$ & 10.7 & 6.7 & 32.0 & 34.7 & 16.0 & 3.38 & 1.16 \\
\hline 6 & $\begin{array}{l}\text { I read stories, poems, and plays to develop my writing } \\
\text { ability. }\end{array}$ & 2.7 & 4.0 & 21.3 & 33.3 & 38.7 & 4.01 & 1.00 \\
\hline 7 & $\begin{array}{l}\text { I can express my thoughts and feelings in an imagi- } \\
\text { native way. }\end{array}$ & 6.7 & 9.3 & 20.0 & 40.0 & 24.0 & 3.65 & 1.14 \\
\hline 8 & $\begin{array}{l}\text { I can attract the readers (my friends and family mem- } \\
\text { bers) to my writings. }\end{array}$ & 13.3 & 10.7 & 13.3 & 37.3 & 25.3 & 3.50 & 1.33 \\
\hline
\end{tabular}

The result for the last sub-classification of writing, creative writing, also reveals the students' positive attitudes towards writing. This could also be seen in item $3(M=4.00 \mathrm{SD}=1.127)$ where $40 \%$ of the respondents strongly agreed that they can support their topics with a lot of ideas when they write. Item $6(\mathrm{M}=4.01 \mathrm{SD}=1.006)$ also show that $38.7 \%$ of the respondents strongly agree that they read stories, poems, and plays to develop their writing ability.

Generally, the findings of the study revealed that the Hausa ESL respondents' attitude toward the writing subscales was positive but with contrasting values of mean as could be seen in Figure 1 below. From the Figure, it shows that the respondents' attitude toward the School Use of English is the highest followed by the Social and the lowest is Creativity.

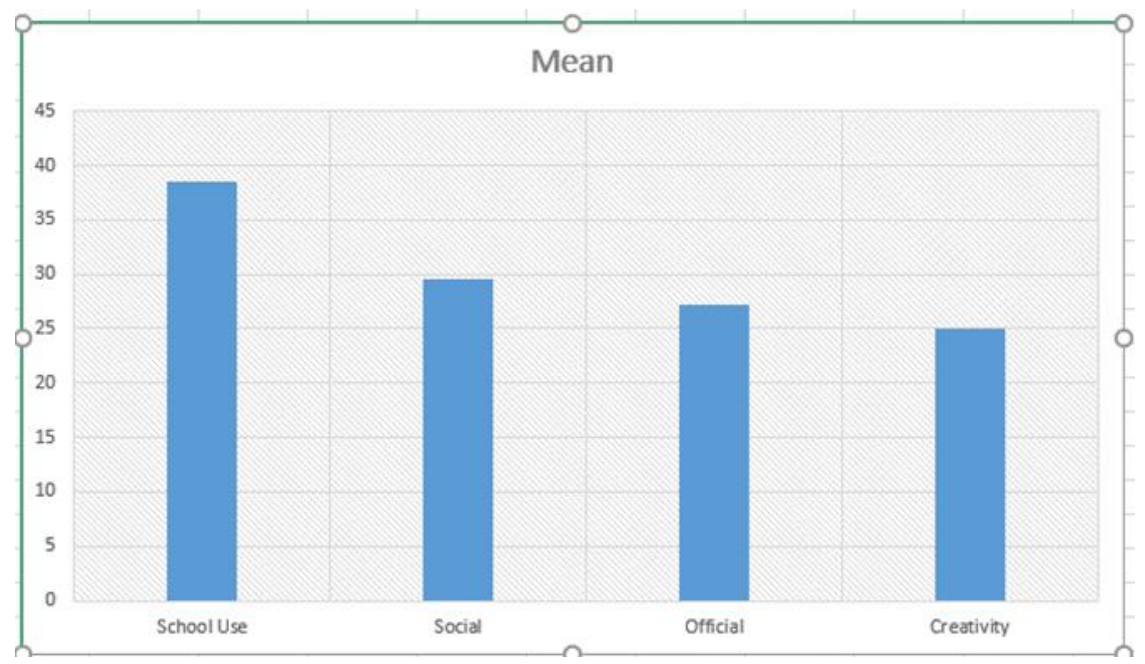


Figure 1. Attitude towards writing

\subsection{Relationship between the Respondents' Attitude towards Spelling and Writing}

The findings of the third research question which investigated the relationship between the respondents' attitude toward spelling and writing in English is presented. To determine the relationship between the students' attitudes toward English spelling and writing, the Pearson correlation coefficient analysis was run. The result is presented in Table 6 below.

Table 6. Spelling and writing attitude relationship

\begin{tabular}{ll}
\hline Pearson correlation & $.573^{* * *}$ \\
Significance (2-tailed) & .000 \\
$\mathrm{~N}$ & 75 \\
\hline
\end{tabular}

${ }^{* *}$ Correlation is significant at the .01 level (2-tailed).

The Table demonstrates that the Pearson correlation coefficient between the students' attitude toward spelling and writing in the English language was $r=.573$. This indicates that there is a significant positive correlation between the respondents' attitude toward the two skills.

The overall results of the study show that most of the respondents have positive attitudes towards English spelling and writing in English. This reveals that most of the respondents are aware of the importance of English spelling and writing. They also believe that a constant practice of writing could improve their spelling performance. They strongly agree that spelling is an essential literacy skill to learn and learning spelling rules enhance their spelling accuracy. This finding agrees with that of Al-Sobhi et al. (2018) which reveals Arabs ESL secondary school students' positive attitudes towards English spellings. However, in Al-Sobhi et al. Social Use is the highest while in this study School Use is the highest in rank in terms of the respondents' positive attitudes. The respondents' preference for writing for School purposes corroborate the findings of other studies which shows that some Nigerian students write in English only for an academic purpose such as assignment and examination (Aliyu, Yong, Mardziah H. Abdullah \& Tan 2016). The respondents' positive attitudes to writing for Creativity is the lowest in the rank. This finding is not surprising because many secondary schools in that part of the country do not have enough teachers of literature in English who should help to stimulate the students' interests in creative writing.

This result of the study further revealed that there is a positive relationship between the respondents' attitudes towards spelling and writing in English. This means that students who have a positive attitude toward English spelling also have a positive attitude toward writing. This also concurs with earlier findings. Graham et al. (2007) 
pointed out that there is a reciprocal relationship between the students' writing attitude and their achievement.

\section{Conclusion}

The main objectives of this study are to examine the Hausa ESL secondary school students' attitude toward spelling and writing and to identify the relationship between attitude toward spelling and writing among the Hausa ESL students. The findings of the study revealed that the students had a positive attitude toward English spelling and writing skills, which reflects the students' awareness of the importance of spelling and writing. Based on the findings of the study, the following conclusion could be made. The problems displayed by the students in their writing in English are not due to negative attitudes towards spelling and writing in English. It could be due to other factors. Secondly, creative writing should be taught and encouraged in secondary school. Extracurricular activities could be organized to help the students to develop their creative writing skills.

\section{Recommendations}

The following are some recommendations for further research. First, future studies should consider a larger sample. This may give a different finding. There is a need to investigate the students' actual writing to ensure their English spelling. Further studies need to investigate other factors that may lead to the students' problems with writing in English. Other variables such as gender, age and educational background should be considered in future studies. In addition, the study recommends that other studies focus on Hausa students' spelling error analysis to investigate their types as well as causes. Error analysis studies may be beneficial, for they can provide researchers with information about the nature of the language learning process. Moreover, identifying learners' errors can help teachers and curriculum designers in the preparation of ESL curriculum, and other teaching materials.

\section{References}

[1] Auster, C, J. (2016). Blended learning as a potentially winning combination of face-to-face and online learning: an exploratory study. Teaching Sociology. 44(1), 39-48.

[2] Badger, R. \& White, G. (2000). A process genre approach to teaching writing. ELT Journal, 54(2), 153-160.

[3] "Best IELTS preparation" (2013). The Importance of Paragraphs in IELTS Writing Retrieved from http://www.bestieltsonline.com/paragraphs-in-ielts-writing-2/

[4] Birgin, O. \& Baki, A. (2007). The use of portfolio to assess student's performance. Journal of Turkish Science Education, 4(2), 75-90.

[5] Bowyer, J. \& Chambers, L. (2017). Evaluating blended learning: bringing the elements together. Research Matters: A Cambridge Assessments Publication, 23, 17-26.

[6] Bridge, P. \& Appleyard, R. (2008). A comparison of electronic and paper-based assignment submission and feedback. Brittish Journal of Educational Technology, 39(4), 644- 
650. Doi: 10.1111/j.1467-8535.2007.00753.x

[7] Brown, G., \& Manogue, M. (2001). Refreshing lecturing: a guide for lecturers. Medical Teacher, 23(3), 231-244. doi: 10.1080/01421590120043000

[8] Bryson, S. (2014). How to structure a paragraph in an academic essay. Retrieved from https://www.scribbr.com/academic-essay/how-to-structure-a-paragraph-in-an-academic-essay/

[9] Davis, K. (2009). Improving motivation and knowledge retention with repeatable lowstakes quizzing. American Society for Engineering Education. 1-7.

[10] Ebner, H. K. (2016). Work conferences and student engagement. Master of Arts in Education Action Research Papers. Paper 153.

[11] Epignosis LLC (2014). E-learning; concepts, trends, applications. Retrieved from http://www.talentlms.com/elearning-101-jan2014-v1.1.pdf

[12] Garrison, D. R. \& Vaughan, N. D. (2008). Blended learning in higher education. John Wiley $\&$ Sons, Inc. San Francisco-USA.

[13] Ghahari, S., \& Ameri-Golestan, A. (2013). The effect of blended learning vs. classroom learning techniques on Iranian EFL learner's writing. International Journal of Foreign Language Teaching and Research, 1(3), 77-86.

[14] Hyland, K. (2003). Second language writing. New York: Cambridge University Press.

[15] Jensen, E. B. (2016). Peer-review writing workshops in college course: students' perspectives about online and classroom-based workshops. Social Sciences, 5(72), 1-17. Dopi: 10.3390/socsci5040072.

[16] Knight, J. K., \& Wood, W. B. (2005). Teaching more by lecturing less. Cell Biology Education, 4(4), 298-310. doi: 10.1187/05-06-0082

[17] Liu, M. (2013). Blended learning in a university EFL writing course: description and evaluation. Journal of Language Teaching and Research, 4(2), 301-309. Doi: 10.4304/jltr.4.2.301-309.

[18] Macdonald, J. (2008). Blended learning and omline tutoring: planning leaner support and activity design (2nd ed.). Hampshire, England: Gower Publishing Limited.

[19] Miles, M. B., Huberman, A. M., \& Saldana, J. (2014). Qualitative data analysis: a methods sourcebook (3rd ed.). California, USA: SAGE Publications, Inc.

[20] Sansivero, G. (2016) Challenges \& advantages of collaborative learning: developing workforce readiness in students. SEEN (SouthEast Education Network) Magazine. http://www.seenmagazine.us/Articles/Article-Detail/ArticleId/5613/CHALLANGESamp-ADVANTAGES-OF-COLLABORATIVE-LEARNING

[21] Savage, A. \& Shafiei, M. (2007). Effective academic writing 1: the paragraph. New York: Oxford University Press.

[22] Spencer, J. (2015). The power of student conferencing. Retrieved from http://www.spenerauthor.com/the-power-of-student-conferencing/

[23] Stein, J. \& Graham, C. R. (2014). Essentials for blended learning: a standards-based guide. Routledge. Third Avenue-New York.

[24] Thorne, K. (2003). Blended learning; how to integrate online and traditional learning. London, UK: Kogan Page Limited.

[25] Tuomainen, S. (2016). A blended learning approach to academic writing and presentation skills. De Gruyter, 3(2), 33-55.

[26] Twigg, C. A, (2003). Improving learning and reducing costs: new models for online learning. Educause Review, 28-38.

[27] Zemach, D. E. \& Islam, C. (2007). Paragraph writing: from sentence to paragraph. London: McMillan.

[28] Zemach, D. E. \& Rumisek, L. A. (2005). Academic writing: from paragraph to essay. Oxford: McMillan. 